\title{
Is self-perceived oral health status related to non-carious cervical lesions in Brazilian working adults?
}

\author{
A autopercepção do estado de saúde bucal está relacionada a lesões cervicais não-cariosas em \\ trabalhadores adultos brasileiros? \\ La autopercepción del estado de salud bucal está relacionada a lesiones cervicales \\ no cariosas en trabajadores adultos brasileños? \\ Rafael Aiello BOMFIM ${ }^{1}$ \\ Edgard CROSATO ${ }^{2}$ \\ ${ }^{I}$ Professor Doutor, Departamento de Saúde Coletiva, Faculdade de Odontologia da Universidade Federal de Mato Grosso do Sul, UFMS 79070-900 Campo Grande-MS, Brasil \\ ${ }^{2}$ Professor Doutor Senior, Departamento de Saúde Coletiva, Faculdade de Odontologia da Universidade de São Paulo, USP05508-000 São Paulo-SP, Brasil
}

\begin{abstract}
This study evaluates the association of Non Carious Cervical Lesions (NCCLs), Oral Health-Related Quality of Life (OHRQoL) and Work Ability Index (WAI) in a Brazilian population of Workers. One hundred workers were evaluated in a CEREST (Worker's Health Reference Center). Participants were examined for oral disease following WHO recommendations, and the Oral Health Impact Profile (OHIP) and Work Ability Index assessment was used to determine OHRQoL and capacity to work, respectively. Assessment of tobacco use and alcohol consumption was made by Fagestron tolerance and Audit test. Statistical analyses were performed using STATA version 13.0. Dimensions with highest OHIP scores were physical pain and psychological discomfort. In bivariate analyses, NCCLs was significant associated with OHIP-14 severity PR 3.8 (CI95\%1.26-11.89) and with self-related of oral pain PR 2.16 (CI95\% 1.06-4.40). In the multivariate logistic regression analyses, years of smoking habits OR 1.73 (CI95\% 1.03-2.9) was significant associated with OHIP-14 severity, independent of other variables. OHIP14 was significant associated to WAI $(\mathrm{p}=0,02)$. Strategies for Monitoring oral health Brazilian workers and reduce tobacco use should be done by Brazilian Companies to support Work ability. For future investigations on OHRQoL, analyses of NCCLs should be included.
\end{abstract}

Descriptors: Quality of Life; Oral Health; Occupational Dentistry; Occupational Health; Tooth Erosion.

\section{Resumo}

Este estudo avaliou a associação de lesões cervicais não-cariosas (LCNCs), qualidade de vida relacionada à saúde bucal (QVRSB) e Índice de Capacidade para o Trabalho (ICT) em uma população brasileira de trabalhadores. Cem trabalhadores foram avaliados em um CEREST (Centro de Referência em Saúde do Trabalhador). Os participantes foram examinados para doença oral seguindo as recomendações da OMS, e a avaliação do Perfil de Impacto da Saúde Bucal (OHIP) e o Índice de Capacidade para o Trabalho (ICT) foram usados para determinar a qualidade de vida e a capacidade de trabalho, respectivamente. A avaliação do uso de tabaco e do consumo de álcool foi feita pela tolerância de Fagestron e pelo teste de Auditoria. As análises estatísticas foram realizadas utilizando o programa STATA versão 13.0. Dimensões com maiores pontuações OHIP foram dor física e desconforto psicológico. Nas análises bivariadas, as LCNCs foram significativamente associadas à gravidade do OHIP-14 PR 3,8 (IC95\% 1,26-11,89) e com dor oral autorrelatada PR 2,16 (IC95\% 1,06-4,40). Nas análises de regressão logística multivariada, anos de tabagismo OR 1,73 (IC95\% 1,03-2,9) foram significativamente associados à gravidade do OHIP-14, independente de outras variáveis. OHIP14 foi significativamente associado ao ICT $(p=0,02)$. Estratégias para monitorar a saúde bucal e reduzir o consumo de tabaco pelos trabalhadores brasileiros devem ser feitas pelas empresas brasileiras para apoiar a capacidade de trabalho. Para futuras investigações sobre QVRSB, as análises de LCNCs devem ser incluídas.

Descritores: Qualidade de Vida; Saúde Bucal; Odontologia do Trabalho; Saúde do Trabalhador; Erosão Dentária.

\section{Resumen}

Este estudio evaluó la asociación de lesiones cervicales no cariosas (LCNC), calidad de vida relacionada a la salud bucal (QVRSB) e índice de capacidad para el trabajo (ICT) en una población brasileña de trabajadores. Cien trabajadores fueron evaluados en un CEREST (Centro de Referencia en Salud del Trabajador). Los participantes fueron examinados para la enfermedad oral siguiendo las recomendaciones de la OMS y la evaluación del perfil de impacto de la salud bucal (OHIP) y el índice de capacidad para el trabajo (ICT) se utilizaron para determinar la calidad de vida y la capacidad de trabajo, respectivamente. La evaluación del uso del tabaco y del consumo de alcohol se hizo por la tolerancia de Fagestron y por la prueba de Auditoría. Los análisis estadísticos se realizaron utilizando el programa STATA versión 13.0. Las dimensiones con mayores puntuaciones OHIP fueron dolor físico y malestar psicológico. En los análisis con dúas variables, las LCNC fueron significativamente asociadas a la gravedad del OHIP-14 PR 3,8 (IC95\% 1,26-11,89) y con dolor oral auto-referida PR 2,16 (IC95\% 1,06-4,40). En los análisis de regresión logística multivariada, los años de tabaquismo OR 1,73 (IC95\% 1,03-2,9) fueron significativamente asociados a la gravedad del OHIP-14, independiente de otras variables. OHIP14 se asoció significativamente a las TIC $(\mathrm{p}=0,02)$. Estrategias para monitorear la salud bucal y reducir el consumo de tabaco por los trabajadores brasileños deben ser hechas por las empresas brasileñas para apoyar la capacidad de trabajo. Para futuras investigaciones sobre QVRSB, las análisis de LCNC deben ser incluidas.

Descriptores: Calidad de Vida; Salud Bucal; Odontología del Trabajo; Salud Laboral; Erosion de los Dientes.

\section{INTRODUCTION}

Previous studies have demonstrated that poor oral health may limit daily activies ${ }^{1}$ and the impact of tooth loss and dental caries on Oral Health Related Quality of Life (OHRQoL) in working adults ${ }^{2-4}$. Adults that have anterior tooth loss and more than four teeth $\operatorname{lost}^{2-4}$ have significative impact on OHRQoL, independent from the instrument measure used, but these investigations doesn't have been adjusted for lifestyle conditions like alcohol consumption and tobacco use, neither adjusted for presence of Non Carious Cervical Lesions (NCCL).

A NCCL is a non-carious related of tooth loss structure at the cement-enamel junction resulted of a multifactorial interactions which includes erosion, abfraction and abrasion processes ${ }^{5,6}$. These conditions may cause gingival resection and root exposure, contributing to tissue abrasion from manual toothbrushing ${ }^{7}$ with exposition of dentine tubules leading to oral pain ${ }^{8}$ that may affect OHRQoL and capacity to work. 
A growing emphasis on subjective measures of oral quality of life is important for public polices, especially on national health polices, that could influence working adults perception at satisfactory levels of health-related quality of life ${ }^{9}$, because it is well known that visiting dentist for oral pain or untreated caries could influence their measures. The clinical oral signs represent only one aspect of overall health, and include subjective measures keeps a teorical concept that differs the traditional biological model of health ${ }^{9}$. For example, Brennan and Teusner ${ }^{10}$ assessed joint effects of oral health and general health functioning problems and reported that for working age adults, oral health was associated with general health for those with more health problems, impacting on OHRQoL scores.

The Work Ability Index (WAI), developed by the Finnish Institute of Occupational Health (FIOH) was validated to be used in Brazilian population and reflects a combination of human resources in relation to social, mental and physical demands that could affect capacity to work, because this account takes into consideration aspects of general health ${ }^{11}$. It could be useful for monitoring Occupational Health and express capacity to work, and it's already known to be related to OHIP-14 scores in a Brazilian worker's population ${ }^{12}$

Thus, the aim of this study was to evaluate if non-carious cervical lesions impact on self-perceived oral health status, and verify WAI and OHRQoL associations in a Brazilian population of working adults, adjusting these conditions for tobacco use and alcohol consumption.

\section{MATERIAL AND METHOD}

\section{Ethical aspects and sample selection}

The study protocol was approved by the local Research Ethics Committee at the University of São Paulo School of Dentistry (process number 101-11 CAAE 0113.0.017.000-11). This was a crosssectional study conducted at a Worker's Health Reference Center, located in the city of Guarulhos, SP, whose coverage includes 10 other nearby cities.

\section{Sample size determination}

The sample size was determined using the formula $\left(n=z^{2} \times ~^{2} / d^{2}\right)$, considering a $95 \%$ level of confidence $(z=1.96)$, which was used to determine the DMFT index, According to the data of national surveys $^{13}$, the standard deviation (SD) of the DMFT index in the southeast region of Brazil for the 35-44 years age group is $7.51 \quad(\mathrm{~s}=7.51)$. The error estimation ( $\mathrm{d}$ value) was measured for 1.5 unit of the DMFT (0.5 unit for each component of the index). By using these values in the formula, we have $\mathrm{n}=$ $(1.96)^{2} \times(7.51)^{2} /(1.5)^{2}=96.25$, so the result was rounded up to a sample size of 100 workers.

We chose to use the 35-44 years age group in the sample size calculation because, according to national epidemiological surveys, this group is the one that best represents the "workers" category. The 65-74 years age group corresponds to elderly and retired individuals, and the preceding 15-19 years age group corresponds to adolescents ${ }^{14}$.

\section{Data collection and oral examination}

Data collection and oral examination was conducted by one investigator (R.A.B.) previously trained to diagnose in the Department of Community Dentistry, University of São Paulo, with WHO recommendations ${ }^{15}$. Consistency was measured by the kappa index. We obtained a value of 0.7 during the first week, but the values were higher than 0.93 in the following weeks, thus indicating substantial agreement. For each 10 workers, one was reexamined to assess intra-examiner agreement ${ }^{14}$

The workers responded to questionnaires regarding personal and social demographic information (name, age, gender, educational level, marital status), occupational information (exposure to acid mists and chemical products, income), reason for seeking assistance at the Worker's Health Reference Center and finally, questionnaires OHIP- $14^{16}$ and $\mathrm{WAI}^{11}$. In an interview with the investigator, the alcohol use disorders identification test (AUDIT) and the Fagerström Tolerance questionnaire were used to assess alcohol consumption and nicotine dependence $^{14}$

All workers were submitted to a clinical dental exam, which was performed on all teeth, including third molars (if present). The DMFT index was assessed in the examination, according to WHO criteria $^{15}$

Instruction for calculation of prevalence and extension of OHIP-14 are available at Slade et al ${ }^{9}$

\section{Diagnostic criteria for untreated NCCLs}

The diagnostic criteria for untreated NCCLs were location in the cervical third of the tooth, no caries, wedge-shaped lesion with sharp edges, or Cshaped lesion with rounded edges.

\section{Statistical analyses}

Frequency distribution and cross tabulation tables were constructed using Microsoft Excel 2013 (Microsoft Inc., Redmond, WA, USA), and the data was processed using the STATA v.13 (Stata Corp., College St., TX, USA).

We use conbrach's alpha test to access OHIP-14 reliability. For statistics that use analyses of NCCLs we excluded edentulous workers $(n=5)$ because they couldn't express formation of NCCLs, minimizing eventual bias. For bivariate analyses of OHIP-14 we use qui square test, and Prevalence ratios (PR) with confidence interval of 95\%, and dichotomized severity of OHIP-14 into lower severity (under 7 points) and upper severity (upper 7 points). 
Associations of WAI index and OHIP-14 score was made by Kruskall Wallis test because values belonged to a no normal curve by Kolmogorov-Smirnov test ( $p>0,05)$.

Qui square test and PR was applied to oral pain (question 3) and worried about teeth (question4) of OHIP-14 questionnaire, respectively to access influence of NCCLs in these impacting dimensions.

\section{RESULTS}

Internal reliability of OHIP-14 questionnaire was analyzed under Cronbach's alpha, with a confidence interval of 95\%. OHIP-14 score was 0,87 , which showed good internal reliability. One hundred workers were eligible to participate in this study. The age of workers ranged from 20 to 68 years old, with a mean range of 44.15 (SD 10.30). The prevalence and extension of OHIP-14 are shown in Table I, according to every dimension of OHIP-14.

Table I. OHIP 14 - Oral health impact profile of workers ( $\mathrm{n}=100)$

\begin{tabular}{|c|c|c|c|c|c|c|}
\hline Dimension & & never & $\begin{array}{l}\text { hardly } \\
\text { ever }\end{array}$ & occasionnally & $\begin{array}{l}\text { fairly } \\
\text { often }\end{array}$ & $\begin{array}{l}\text { very } \\
\text { often }\end{array}$ \\
\hline \multirow{2}{*}{$\begin{array}{l}\text { Functional } \\
\text { limitation }\end{array}$} & $\begin{array}{l}\text { difficulty to } \\
\text { speak }\end{array}$ & 74 & 7 & 15 & 1 & 3 \\
\hline & taste of food & 64 & 19 & 16 & 0 & 1 \\
\hline \multirow[b]{2}{*}{ Physical pain } & & 27 & 23 & 38 & 7 & 5 \\
\hline & $\begin{array}{l}\text { Discomfort } \\
\text { when eating }\end{array}$ & 35 & & 34 & & 5 \\
\hline \multirow{2}{*}{$\begin{array}{l}\text { Psychological } \\
\text { discomfort }\end{array}$} & worried & 25 & 23 & 42 & 4 & 6 \\
\hline & $\begin{array}{c}\text { tense } \\
\text { unsatisfactory }\end{array}$ & 47 & 18 & 28 & 1 & 6 \\
\hline \multirow[t]{2}{*}{$\begin{array}{l}\text { Physical } \\
\text { discomfort }\end{array}$} & & 47 & 22 & 26 & 2 & 3 \\
\hline & & 76 & 10 & 11 & 2 & 1 \\
\hline \multirow[t]{2}{*}{ Social disability } & $\begin{array}{l}\text { peaple } \\
\text { difficulty in } \\
\text { daily }\end{array}$ & 60 & 24 & 12 & 1 & 3 \\
\hline & $\begin{array}{l}\text { activities } \\
\text { difficult to }\end{array}$ & 44 & 15 & 24 & 6 & 11 \\
\hline \multirow{2}{*}{$\begin{array}{l}\text { Psycological } \\
\text { dosability }\end{array}$} & relax & 82 & 9 & 8 & 1 & 0 \\
\hline & $\begin{array}{l}\text { embarassed } \\
\text { unsatisfied }\end{array}$ & 75 & 16 & 6 & 2 & 1 \\
\hline \multirow[t]{2}{*}{ handicap } & $\begin{array}{l}\text { with life } \\
\text { unable to do }\end{array}$ & 77 & 11 & 9 & 1 & 2 \\
\hline & daily tasks & 89 & 4 & 4 & 2 & 0 \\
\hline Prevalence & $38 \%$ & & & & & \\
\hline Extent & 0,82 & & & & & \\
\hline Severity & $10,21(\operatorname{sd} 8$ & & & & & \\
\hline
\end{tabular}

Table II shows bivariate analyses of OHIP-14 with several others independent variables. We note that was significant association of OHIP-14 with presence or absence of NCCLs $(\mathrm{p}=0,02)$ and years of smoking (when stratified above 15 years of smoking and under 15 years) OR 1.87 (CI95\% 1.01-7.43).

Table III shows logistic regression in the multivariate model showing us a log-likelihood of 65.1106 , and the independent variable "years of smoking" was significative associated and independent of other variables.

Table IV shows significative association of OHIP-14 and WAI index, by Krukall Wallis Test $(\mathrm{p}<0,05)$, and no significative associations for oral health indicators (DMFT index and stratifications).

NCCLs were analyzed with more impacting questions on severity of OHIP-14, questions 3 and 4. This analyses show us a significative association of self-report oral pain with NCCLs with PR of 2,16 (CI95\% 1,06-4,40) showed in table V.

Table II. Bivariate analyses OHIP-14 - severity

\begin{tabular}{|c|c|c|c|c|c|}
\hline & lower & higher & PR & CI95\% & $\mathbf{p}$ \\
\hline \multicolumn{6}{|l|}{ Sex } \\
\hline male & 21 & 34 & 1 & \multirow{2}{*}{$0.69-1.45$} & \multirow{2}{*}{0.96} \\
\hline female & 17 & 28 & 1.01 & & \\
\hline \multicolumn{6}{|l|}{ Age group } \\
\hline $18-34$ & 8 & 11 & 1 & & \\
\hline $35-44$ & 11 & 18 & 1.19 & $0.31-4.50$ & 0.77 \\
\hline$>45$ & 19 & 33 & 1.26 & $0.37-4.17$ & 0.66 \\
\hline \multicolumn{6}{|l|}{ Income } \\
\hline under US\$ 500 & 20 & 39 & 1 & & \\
\hline above US\$ 500 & 18 & 23 & 0.65 & $0.26-1.61$ & 0.31 \\
\hline \multicolumn{6}{|l|}{ Schooling } \\
\hline above middle & 22 & 39 & 1 & & \\
\hline under middle & 16 & 23 & 0.81 & $0.32-2.01$ & 0.61 \\
\hline \multicolumn{6}{|l|}{ NCCLS } \\
\hline absence & 14 & 8 & 1 & & \\
\hline presence & 23 & 50 & 3.8 & $1.26-11.89$ & 0.007 \\
\hline \multicolumn{6}{|l|}{ Oral lesions } \\
\hline yes & 6 & 13 & 1 & & \\
\hline no & 32 & 49 & 0.8 & $0.39-1.63$ & 0.52 \\
\hline \multicolumn{6}{|c|}{$\begin{array}{c}\text { Treatment need for } \\
\text { caries }\end{array}$} \\
\hline yes & 24 & 43 & 1 & & \\
\hline no & 14 & 19 & 0.84 & $0.51-1.41$ & 0.52 \\
\hline \multicolumn{6}{|l|}{ Lost $4+$ teeth } \\
\hline yes & 22 & 40 & 1 & & \\
\hline no & 16 & 22 & 0.84 & $0.51-1.39$ & 0.50 \\
\hline \multicolumn{6}{|l|}{ Fagestron tolerance } \\
\hline yes & 9 & 22 & 1 & & \\
\hline no & 29 & 40 & 0.69 & $0.37-1.28$ & 0.21 \\
\hline \multicolumn{6}{|c|}{ Alcohol consumption } \\
\hline 0 & 23 & 33 & 1 & & \\
\hline others & 15 & 29 & 1.20 & $0.72-2.02$ & 0.47 \\
\hline \multicolumn{6}{|l|}{ Years of smoking } \\
\hline under 15 years & 28 & 33 & 1 & & \\
\hline above 15 years & 10 & 29 & 2.46 & $1.00-6.63$ & 0.04 \\
\hline
\end{tabular}

Table III. Unconditional logistic regression analysis of OHIP-14 severity.

\begin{tabular}{|c|c|c|c|}
\hline Variables Final Model & OR & CI $95 \%$ & $\mathbf{P}$ \\
\hline Age group ${ }^{a}$ & 0.74 & 0.36 to 1.52 & 0.42 \\
\hline Years of smoking ${ }^{b}$ & 1.73 & 1.03 to 2.9 & 0.03 \\
\hline Caries $^{f}$ & 1.44 & 0.57 to 3.63 & 0.42 \\
\hline WAI $^{\mathrm{g}}$ & 1.04 & 0.61 to 1.77 & 0.88 \\
\hline Lost 4 or + teeth $^{\mathrm{h}}$ & 0.77 & 0.26 to 2.27 & 0.64 \\
\hline Schooling ${ }^{c}$ & 1.01 & 0.40 to 2.54 & 0.42 \\
\hline Alcohol use ${ }^{\mathrm{d}}$ & 0.95 & 0.40 to 2.25 & 0.92 \\
\hline $\mathrm{NCCLs}^{\mathrm{e}}$ & 1.61 & 0.57 to 4.50 & 0.36 \\
\hline 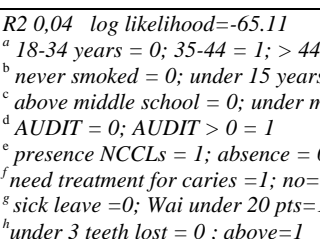 & $\begin{array}{l}=1 ; a b \\
\text { hool }=\end{array}$ & ars $=2$ & \\
\hline
\end{tabular}

Table IV. Association WAI with OHIP-14 and oral health indicators (DMFT)

\begin{tabular}{cccccccccc}
\hline WAI & & DMF & D & M & F & NCCLs & $\begin{array}{c}\text { n } \\
\text { teeth }\end{array}$ & $\begin{array}{c}\text { Ohip } \\
\text { 14 }\end{array}$ & $\begin{array}{c}\text { Age- } \\
\text { mean }\end{array}$ \\
\hline Sick leave & 20 & 15,85 & 2,25 & 9,6 & 3,55 & 3,35 & 20,55 & 10 & 47,1 \\
Low & 43 & 15,48 & 2,11 & 8,13 & 4,86 & 2,67 & 21,97 & 13,44 & 42,58 \\
Moderate & 33 & 16,72 & 2,09 & 10,84 & 3,54 & 3,93 & 18,33 & 7,87 & 43,63 \\
Good & 4 & 16,5 & 2,25 & 6 & 7,25 & 7,25 & 23,5 & 5,75 & 50,5 \\
\hline p & & 0,90 & 0,99 & 0,55 & 0,22 & 0,12 & 0,29 & 0,01 & 0,24 \\
\hline
\end{tabular}

Kruskall-Wallis test

Table V. Bivariate analyses NCCLs with oral pain and worried selfrelated

\begin{tabular}{|c|c|c|c|c|c|}
\hline & \multicolumn{2}{|c|}{ Oral Pain Related } & \multirow[t]{2}{*}{ PR } & \multirow[t]{2}{*}{ CI95\% } & \multirow[t]{2}{*}{$\mathbf{p}$} \\
\hline NCCLS & no & yes & & & \\
\hline no & 9 & 13 & 1 & \multirow{3}{*}{$1.06-4.40$} & \multirow{3}{*}{0,03} \\
\hline yes & 14 & 59 & 2.16 & & \\
\hline & & Wo & & & \\
\hline NCCLS & no & yes & & & \\
\hline no & 9 & 13 & 1 & \multirow[b]{2}{*}{$0.59-2.60$} & \multirow{2}{*}{0.56} \\
\hline yes & 25 & 48 & 1.26 & & \\
\hline
\end{tabular}




\section{DISCUSSION}

In the present research we found a OHIP-14 prevalence (\% of people reporting $1+$ impacts fairly/very often) of 38\% that is above Australian $(18,2 \%)$ and United Kingdom $(15,9 \%)$ population $^{9}$ but this prevalence was similar to another Brazilian working population ${ }^{3}$ but under the $48,1 \%$ of residents in Piracicaba, Brazil ${ }^{2}$. This indicates that public policies by Brazilian government should consider create healthier work place environments, an important tool to one of the WHO goals for the year 2020 to reduce impact of oral health and psychosocial development ${ }^{17}$.

We found OHIP-14 severity mean of 10,21 with is similar other study in a Brazilian residents in Piracicaba that found a mean of $10,21^{2}$ and above 7.70 of other study with Brazilian's workers of a textile company ${ }^{12}$ and above the 4.55 of a workers population of a public university ${ }^{18}$.Differences maybe could be explained by schooling. Employers of the textile company, $71 \%$ has university graduation and belongs to administrative services and in the present research, only $1 \%$ has university. Workers that has better schooling has a better income and it determines much more dentist visits, reducing impact on OHRQoL. Educational level was significant and independent of other variables that affects OHIP-14 severity ${ }^{12}$. The lower values for workers of public university could be explained by being education workers feeling about face appearance ${ }^{18}$.

OHIP-14 extent (mean number of items reported fairly/very often), in the present research, was 0.82 , values above 0.36 for UK population and 0.46 for Australian dentate population and 0.72 for Australian edentulous population ${ }^{9}$. Even with methodological considerations, in the present research we use an interview-administered collection of data questionnaires, and not a self-completed questionnaires that were used in Australia, the values of OHIP-14 extent was upper the two countries. Low income and low schooling of workers in the present research could explain it.

Previous studies have demonstrated the impact of tooth loss and dental caries on OHRQoL in working adults ${ }^{2,3}$ but these studies does not have been adjusted for lifestyle conditions like alcohol consumption and tobacco use, neither for NCCLs. Our study does not associated with dental caries, neither tooth loss of four or more teeth. It is unknown why these conditions affect quality of life, being a challenge for epidemiological studies ${ }^{2}$. The explanation for OHRQoL were not associated with tooth loss, maybe could be a large number of workers with oral periodontal problems, seen in periodontal pocket. This workers need extraction, but with difficult to dental care access, remains with teeth that need extraction (26\% of workers) and $38 \%$ has periodontal pocket more than $3 \mathrm{~mm}$. The present research showed that posterior tooth loss was significant in relation to anterior tooth loss $(\mathrm{p}<0,001)$ in all years group ( $18-34$ years; 35-44;45-67), and it could explain the lower impact (absence of significant association) with tooth loss (more or less than 4 teeth) and OHRQoL, which is in agreement with another finding ${ }^{4}$.

The association of OHIP-14 severity (bivariate analyses) with presence of Non-carious cervical lesions $(p=0,007)$ has biological plausibility, because NCCLs may cause dentine hypersensitive (8) with impacts on oral pain, a very significant dimension of OHRQoL. Physical oral pain, maybe by formation of NCCLs, and physiological discomfort (being worried about teeth), was the two dimensions that more impact OHRQoL with $(73 \%$ and $75 \%)$ of self-perceived impact, agreeing with other findings ${ }^{2}$, 3,12,18-20. This research showed a significant association of NCCL with question 3 of OHIP instrument (oral pain in the last 6 months), one of the most important dimension, with PR of 2,16 (CI95\% 1,06-4,40). Associations of NCCLs and OHRQoL have to be investigated in futures researches.

The logistic regression model to perform the severity ( impacts under 7 points and impacts over 7 points) associate prevalence of OHIP-14 to years of smoking habits (specifically more than 15 years of smoking) and independent of other variables. The explanation for this fact is that smoking for a long period of time may lead to gingival resection, formation of NCCLs, periodontal problems, alter salivary $\mathrm{Ph}$. Strategies of reducing tobacco use in workplace should be adopted immediately for Brazilian companies.

The work ability index, developed by the Finish Institute of Occupational Health (FIOH) had significative association with OHIP-14 severity, with can impact on how a worker feels in your occupational activity. This association justifies actions related to promotion and protection's oral health workers. This evidence reinforces the importance to integrate occupational oral health activities and health care in Brazilian Companies. In a recent future these actions could be added in Health Family Strategy. This information of OHRQoL precedes clinical exams and could be made by Communitarian agents in domiciliary visits being oriented and prior to public access of workers ${ }^{19}$.

Campaigns against tobacco use in much could favor the condition of oral health of workers, and promote the systemic health. Ramseier et al. ${ }^{21}$ reported that the use of tobacco has been a risk factor for cancer and periodontal disease. Help people quit smoking could also be responsibility of oral health teams, and should be supported by behavioral actions accompanied by pharmacotherapy. Governments should give the correct support to oral health 
professionals in an attempt to try to promote initiatives for the population, the community and the workers as much this tend strategies to improve the oral health condition. Action against tobacco use, conducted by the Health Family Strategy, supported by public policies could help to promote a more favorable oral environment against various oral diseases resulting from tobacco use ${ }^{21}$.

This study also allows the Dentist to define strategies "high risk" in occupational oral health services, for example, by a worker who smokes, and have NCCLs. This concept of "risk" strategy has been questioned in the literature ${ }^{22}$ where the present author posited the question: Could a small increase in disease in a large number of individuals from "no risk" generate a wider range of diseases than a large increase in a group of diseases in "risk" of a few individuals? It is to emphasize that this risk strategy will depend on the population of workers, so we must always stick to the population characteristics, the prevalence, risk factors of diseases as well as their age profile.

\section{CONCLUSION}

In the group of workers examined, NCCLs and years of smoking was significative associated with OHRQoL dimensions, measured by OHIP-14 questionnaire. Companies are urged to monitor brazilian's workers oral health, and self-perceived oral health status is an important tool. These strategies may improve work ability and capacity to work.

\section{REFERENCES}

1. Tsakos G, Allen PF, Steele JG, Locker D. Interpreting oral health-related quality of life data. Community Dent Oral Epidemiol. 2012; 40(3):193-200.

2. Batista M, Lawrence H, de Sousa M. Impact of tooth loss related to number and position on oral health quality of life among adults. Health Qual Life Outcomes. 2014; 12:165.

3. Batista MJ, Perianes LB, Hilgert JB, Hugo FN, Sousa Mda L. The impacts of oral health on quality of life in working adults. Braz Oral Res. 2014; 28. pii: S1806-83242014000100249.

4. Gerritsen AE, Allen PF, Witter DJ, Bronkhorst EM, Creugers NH. Tooth loss and oral healthrelated quality of life: a systematic review and meta-analysis. Health Qual Life Outcomes. 2010; 8:126.

5. Aw T, Lepe $\mathrm{X}$, Johnson $\mathrm{G}$, Mancl L. Characteristics of noncarious cervical lesions - A clinical investigation. J Am Dent Assoc. 2002; 133(6):725-33.

6. Lussi A, Jaeggi T. Erosion - diagnosis and risk factors. Clin Oral Investig. 2008; 12(Suppl 1):S5-13.
7. Wiegand A, Burkhard J, Eggmann F, Attin T. Brushing force of manual and sonic toothbrushes affects dental hard tissue abrasion. Clin Oral Investig. 2013; 17(3):815-22.

8. Scaramucci T, de Almeida Anfe TE, da Silva Ferreira S, Frias AC, Sobral MA. Investigation of the prevalence, clinical features, and risk factors of dentin hypersensitivity in a selected Brazilian population. Clin Oral Investig. 2014; 18(2):65157.

9. Slade GD, Nuttall N, Sanders AE, Steele JG, Allen PF, Lahti S. Impacts of oral disorders in the United Kingdom and Australia. Br Dent J. 2005; 198(8):489-93.

10. Brennan DS, Teusner DN. Oral health impacts on self-rated general and oral health in a crosssectional study of working age adults. Community Dent Oral Epidemiol. 2015; 43(3); 282-88.

11. Monteiro MS, Ilmarinen J, Correa Filho HR. Work ability of workers in different age groups in a public health institution in Brazil. Int $\mathbf{J}$ Occup Saf Ergon. 2006; 12(4):417-27.

12. Bomfim RA, Crosato EM, Mazzilli LEN. Relations between oral health and work ability among administrative workers. Braz J Oral Sci. 2015; 14(1):41-5.

13. Roncalli AG, Silva NN, Nascimento AC, Freitas CHSM, Casotti E, Peres KG et al. Aspectos metodológicos do Projeto SBBrasil 2010 de interesse para inquéritos nacionais de saúde. Cad Saude Publica. 2012; 28(Sup):S40-57

14. Bomfim RA, Crosato E, Mazzilli LE, Frias AC. Prevalence and risk factors of non-carious cervical lesions related to occupational exposure to acid mists. Braz Oral Res. 2015; 29(1):1-8.

15. Gelbier S. Book Reviews. Oral health surveys basic methods. World Health Organization. Int J Epidemiol. 1977; 6(4):405-6.

16. Oliveira BH, Nadanovsky P. Psychometric properties of the Brazilian version of the Oral Health Impact Profile-short form. Community Dent Oral Epidemiol. 2005; 33(4):307-14.

17. Petersen PE, Kwan S. The 7th WHO Global Conference on Health Promotion - towards integration of oral health (Nairobi, Kenya 2009). CDH. 2010; 27(Suppl 1):129-36.

18. Campos Guerra MJ, Greco RM, Goncalves Leite IC, Ferreira e Ferreira E, Queiroz de Paula MV. Impact of oral health conditions on the quality of life of workers. Cienc Saude Colet. 2014; 19(12):4777-86.

19. Lacerda JT, Ribeiro JD, Ribeiro DM, Traebert J. Prevalence of orofacial pain and its impact on the oral health-related quality of life of textile industries workers of Laguna, SC, Brazil. Cienc Saude Colet. 2011; 16(10):4275-82. 
20. Lacerda JT, Traebert J, Zambenedetti ML. Orofacial pain and absenteeism in workers of the metallurgic and mechanics industry. Saude Soc. 2008; 17(4):182-91.

21. Ramseier CA, Warnakulasuriya S, Needleman IG, Gallagher JE, Lahtinen A, Ainamo A et al. Consensus Report: 2(nd) European workshop on tobacco use prevention and cessation for oral health professionals. Int Dent J. 2010; 60(1):3-6.

22. Batchelor P, Sheiham A. The limitations of a 'high-risk' approach for the prevention of dental caries. Community Dent Oral Epidemiol. 2002; 30(4):302-12.

\section{CONFLICTS OF INTERESTS}

The authors declare no conflicts of interests.

CORRESPONDING AUTHOR

Rafael Aiello Bomfim

aiello_rafael@gmail.com

Received 28/05/2018

Accepted 27/06/2018 